\title{
A közszolgálati fegyelmi felelősség kezdetei a polgári kori Magyarországon
}

\section{The Beginnings of the Hungarian Disciplinary Liability of Public Service in the Dualism}

\begin{abstract}
SALLAI B. ${ }^{1}$
Debreceni Egyetem, Állam- és Jogtudományi Kar, sallaibalazs1998@gmail.com University of Debrecen, Faculty of Law, sallaibalazs1998@gmail.com

Absztrakt

A jelen irás témája a közszolgálati fegyelmi felelösség magyar szabályozása a dualizmusban, ezen belül is leginkább az, hogy e jogintézmény dogmatikai elemei hogyan alakultak, fejlödtek és bövültek ki a XIX. században. Ennek a folyamatnak a megismerése azért is bir kiemelt jelentőséggel, mert a ma is ismert fegyelmi eljárás - és föként annak sok garanciális jelentőségü mozzanata - ekkor bontakozott ki, ám nem éppen mentesen a szakmai vitáktól. A kutatás Debrecen város közigazgatási területére fókuszál, s levéltári anyagok feldolgozása mentén a fegyelmi jog érvényesülését és alkalmazását vizsgálja kiemelten, illetve az 1886. évi XXIII. törvénycikk szerint eljárást ismerteti egy konkrét eseten keresztül. A már ismertetetteken túlmenöen röviden a közszolgálati jogviszony „kezdetleges” meghatározásai, jogelméleti megközelitései is bemutatásra kerülnek egyfajta elhelyezést segitö kontextusát képezve a közszolgálati felelösség rendszerének, $s$ azon belül pedig a közszolgálati fegyelmi felelösségnek.
\end{abstract}

Kulcsszavak: dualizmus, jogtörténet, közigazgatás, közigazgatási felelősségi rendszer, fegyelmi eljárás

Abstract

The subject of this paper focuses on the hungarian regulation of the disciplinary law of the civil service in Dualism, in particular how the dogmatic elements of this legal institution evolved, developed and expanded in the $19^{\text {th }}$ century. It is also important to know that this process because the disciplinary procedure we know today - and especially its many aspects of warranty - came into being at this time, but not without any professional debate. The research focuses on the administrative area of Debrecen and the enforcement and application of disciplinary law describing the disciplinary procedure of $23^{\text {rd }}$ Act of 1886 through a case. (This act regulated the disiplinary procedure between 1886 and 1929). In addition to what has already been described, the 'rudimentary' definitions of the public service relationship is also presented as a mentioned placement of the liability system of the civil service, and containing public service disciplinary liability. Moreover this paper present the disiplinary system's essence based on the $42^{\text {nd }}$ Act of 1870 and $7^{\text {th }}$ Act of 1876.

Keywords: Dualism, legal history, administrative law, liability system of civil service, disciplinary proceedings

JEL: K39

\section{Bevezetés}

Az alábbi írás témája a közszolgálati fegyelmi felelősség szabályozása a dualizmus - kori Magyarországon. A tanulmány igyekszik górcső alá venni a jogszabályi háttér és a jogdogmatikai

${ }^{1}$ ORCID: 0000-0002-6897-2872 
tézisek mellett a gyakorlati életből merített példákat is, amelyek segítségünkre lehetnek, ha szeretnénk megérteni a fegyelmi vizsgálatra és eljárásra vonatkozó normák érvényesülését és müködését. $\mathrm{E}$ metódust az indokolja, hogy a napjainkban is élő jogintézményt általánosságban kell megismernünk legfőképp történeti fejlődéséhez igazodva -, hiszen e nélkül nem tanulhatunk a régmúlt esetleges jogalkotói hibáiból, s nem tehetjük mind kifinomultabbá egyfelől a fegyelmi eljárás garanciarendszerét, másfelől társadalomvédő funkcióit, amely utóbbi funkciókra való tekintettel tartjuk fenn napjainkban is e felelösségi formációt a közszolgálat valamennyi területén. Ahhoz azonban, hogy a felelősség e formájának kialakulását megértsük, szükséges elöljáróban néhány jelentősebb összefüggést tisztázni. A legelső ilyen kérdéskör arra vonatkozik, hogy kiket is tekinthetünk közszolgálatban állóknak és, hogy mi indokolja a közszolgálatban álló dolgozók speciális felelősségre vonhatóságát (amely nem csak a fegyelmi, hanem más formákat is magában foglal).

\section{Mi a közszolgálat?}

A közszolgálattal foglalkozó irodalom szinte végtelen számú műve próbálta már meg a közszolgálat egységes definícióját megadni. A jelen munka csupán érintőlegesen foglalkozik e témával, s így egyes lehetséges fogalmi elemeket mutat be, amelyek a téma szempontjából relevanciával bírnak. Az első ilyen a közérdek (necessitas publica) és a közjó (bonum publicum) fogalompár, (Kelemen, 2016: 234) amely funkcionális szempontból alapozza meg az állam azon kötelezettségét, hogy ezeket valamilyen apparátus útján biztosítsa. Ez az állami apparátus - amelyre a kontinensen általában valamilyen elkülönült (köz)jogi szabályozás vonatkozik - sok elemet foglal magában, ám ezek az idők során cserélődtek. A most tárgyalt korszakban a magyar szabályozásban ide tartoztak például a bírók, ügyészek, tanítók, orvosok, közigazgatási dolgozók, ez utóbbiak különböző rangokban és beosztásban. Az alábbi részekben azonban a közszolgálat szükebb értelmezésével operálunk, amely csak a közigazgatás dolgozóit jelenti. Ezt a szükebb értelmet tükrözi a következő definíció: „A közszolgálat az állam (törvényhatóság, község) nevében kifejtett müködés, az állami akaratnak egyes esetekben való konkrét megvalósitása." (Sávoly, 1934: 5) Egységes szolgálati pragmatika hiányában az egyes ágazati jogszabályokból deríthetők ki a közszolgálat alrendszerén belül elhelyezkedő beosztások fogalmai (Sávoly, 1934: 8-10).

\section{A közszolgálati felelösség alkotmányos alapjai}

A felelősség indokainak tárgyalása során a gyökerektől érdemes kezdenünk, nevezetesen a hatalommegosztás elvétől. Ennek a modern államalakulatok müködési mechanizmusait átható gondolatkörnek ma már más meghatározásai is ismertek, (Csink, 2013: 127-136) azonban a legegyszerübb, legismertebb és a jelen korszak tekintetében legadekvátabb a Montesquieu - féle elképzelés, bár a hatalommegosztás elméletének gyökerei Arisztotelészig nyúlnak vissza. (Cservák, 2015: 12-13) A montesquieui elgondolás szerint az elválasztott hatalmi ágaknak (törvényhozás, végrehajtás, igazságszolgáltatás) müködésükben egymástól függetleneknek kell lenniük, és egyenrangúságuk megörzése érdekében egymást kölcsönösen ellenőrizniük kell azért, hogy az állami müködés önkényességét elkerüljük.

A végrehajtó hatalmi ágat és annak csúcsszervét, a kormányt kell leginkább folyamatos és hatékony ellenőrzési mechanizmusnak alávetni, mivel a legjelentősebb társadalmi források itt összpontosulnak, tehát cselekvési szabadságát tekintetbe véve ezen ág képes a leggyorsabban másik kettő fölé kerekedni. A már említett ellenőrzés gyakorlati megvalósítására különböző intézmények alakultak ki az alkotmányjogban. Nálunk és más nemzeteknél (legalábbis a kontinensen tipikusan) a parlamentarizmus honosodott meg, ahol a végrehajtó hatalom (pontosabban a kormány) felelőssége a mindenkori Országgyülés felé áll fenn. (Ennek számtalan eszköze létezett és létezik ma, például a 
kérdés, az interpelláció, a vizsgálóbizottság, a konstruktív bizalmatlansági indítvány, Állami Számvevőszék különböző jogosítványai stb.) A törvényhozás tehát a kormányt általános politikai és jogi intézkedései miatt felelősségre vonhatta. A kormány azonban - a dualizmusban de facto - az egész közigazgatási szervezetrendszer hierarchiájának legmagasabb pozícióját foglalta el, s az alárendelt szervek útján, a kellő - mai szóhasználattal élve - demokratikus legitimációval felruházva valósította meg politikáját, illetve hajtotta végre a törvényeket. Mivel azonban ezen említett alsóbb szintü szerveknél alkalmazásban lévő dolgozók sokszor nem a kormány, hanem saját érdekeiket - amely érdekeket nem a választópolgárok legitimáltak - helyezhették előtérbe, vagy legalábbis számításba vették azokat az említett tevékenységek végzése során, (Győrfi, 2001: 82-83) ezért szükségesnek mutatkozott egy olyan rendszer kialakítása, amely a kormányt biztosította arról, hogy nem kell olyan jelenségek miatt felelnie az Országgyülés előtt, amelyekre befolyásuk vagy azokról tudomásuk nem volt. Ezen a ponton jutunk el tehát a közszolgálati felelősség elvi szükségességének tényéhez. Röviden összefoglalva azt mondhatnánk: a kormány tagjait vagy egészét nem terhelheti szankcióval fenyegető felelősség a tőlük függetlenül bekövetkezö, a társadalomban általában negatív hatásként megítélt egyedi esetekért.

Ezt a jelenséget szükebb értelemben a politikai felelősség (politikai kontroll) (Győrfi, 2001: 83) megalapozásának szokás tekinteni, ám alkalmas egyéb jogállamiságból eredő indokok - például az, hogy egy modern állami berendezkedésben a közigazgatásnak felelnie kell cselekedeteiért; ezen elv kimondását a francia Blanco- ítélethez (1873) szokták kötni (Szigeti - Takács, 1998: 207) - mellett a közszolgálati felelősségi rendszer szükségességének alátámasztására. A következőkben tekintsük át röviden, mit is jelent ez a már sokat emlegetett közszolgálati felelösségi rendszer! A klasszikusnak számító meghatározás szerint a tárgyalt terminus három elemet foglal magában: a vagyoni, a fegyelmi és a büntetőjogi felelősséget. Ezzel szemben persze léteznek más, speciálisabb felelősségi formák, így például a miniszteri (Cserny, 2011; Szabó, 2017) vagy az államjogi felelősség (Szamel, 1986: 226-241), de léteznek másféle csoportosítások is. (Szamel, 1986; Veszprémi, 2011) Most azonban fogadjuk el a klasszikus felosztást, amely mindhárom elemének megtalálható kialakulási oka, valamint specifikus elvi megalapozása. Ezek ismertetésétől a továbbiakban eltekintünk, s csak a fegyelmi felelősségre koncentrálunk.

\section{A fegyelmi felelősség elözményei}

A fentebb vázoltak alapján most már értelmezhetővé vált a következő gondolat első fele: „, $[\ldots] a$ fegyelmi jog kiindulópontja maga a közszolgálat és annak az érdeke, a jog érvényesitését mégis bizonyos jogi korlátokkal kell körülvenni, különösen az eljárást illetőleg.” (Tomcsányi, 1926: 360) Az első részből kitűnik: alapvető - elsősorban kormányzati, de legalább felettesi - érdek az, hogy létezzen a fegyelmi felelősség. Másrészt viszont a közszolgálati jogviszonyban állónak érdeke az, hogy a fegyelmi eljárás megfelelő garanciákkal bírjon számára, megakadályozandó, hogy az csak puszta fegyverként legyen felhasználható ellene. Ez lesz a tárgyalt felelősségi alakzat két, egymással ellentétes oldala. Ezek azonban nem voltak adottak első pillanattól fogva. A fegyelmi felelősség előképeinél még csak az állami hatalom oldala található meg, erös diszkrecionális jogkörrel, általános szabályok nélkül. Ennek kiindulását a fejlett bürokratikus szervezet megteremtése idején érdemes keresnünk, ez pedig a XVIII. század abszolutista szellemiségü dikaszteriális igazgatásának időszakára esik. A dikaszteriális igazgatás már modernnek volt mondható abban az értelemben, hogy az egyes ügyek intézése témák szerint oszlott meg, s ezeket az ügyeket egy, az adott területen szakképzettséggel, vagy legalábbis gyakorlattal rendelkező személy intézte. A szakképesített és a közszolgálati jogviszonyt megalapozó és „életpályamodellel” rendelkező hivatalnokréteg tagjai azonban még nem valamilyen általánosabb, széles körben alkalmazandó jogszabály alapján jártak el, hanem kifejezetten személyükhöz intézett, felettesi utasítások - amelyek vonatkozhattak konkrét ügyre vagy ügyek egy csoportjára - ún. 
individuális normák figyelembevételével. (Héjja, 2015: 1069) Ezeket a felettes által kiadott instrukciókat az egyes személyeken már számon lehetett kérni. Ezzel csak az volt a gond, hogy a nagyszámú individuális norma táptalaját képezte a hatásköri problémáknak, $\mathrm{s}$ a kaotikus állapotok miatt nagy számban fordultak elő hibák. (Héjja, 2015: 1070, 1073) Természetesen a tisztviselőknek felróható hibák szankcionálása már ekkor kialakult, ám még korántsem beszélhetünk fegyelmi felelősségről.

A tisztviselő normaellenes cselekménye ugyanis vagy büntetendő cselekménynek számított, $\mathrm{s}$ ezért vonták felelősségre (a büntetőjog akkori szabályai szerint), vagy ha nem valósított meg büntetendő cselekményt, de valami miatt sérelmes volt a felettes vezetésre nézve, akkor lehetöség volt a jogi fogalomkészlettel nehezen értelmezhető „parttalan politikai felelösség” (Szamel, 1986: 229) eszközével élni. Ez utóbbi tekintetében felmerül a kérdés, mi tekinthető sérelmesnek? A válasz pedig: minden, ami a felettes(ek) gondolkodása szerint szemben áll valamilyen jogforrással vagy bármilyen más (ad abszurdum személyes) érdekkel. Ebből is láthatjuk tehát, hogy erős diszkrecionális jogkörről beszélhetünk e kérdés kapcsán. A fentiekből az is következik, hogy a büntetőjogi felelősség sokkal hamarabb alakult ki, mint más közszolgálati felelősségi forma. A fegyelmi felelősség kezdeteit akkorra tehetjük, amikor egyrészt „a fegyelmi vétségek a közönséges büntettöl s vétségtöl” elválasztásra kerültek, (Gálbory, 1929: 4) másrészt amikor ezek megvizsgálása és megítélése valamilyen általános formát (eljárási rendet) kezdett elnyerni. Fontos azonban hangsúlyozni, hogy a fegyelmi jog nem a büntetőjogi felelősségből nőtt ki, azzal teljesen egyenrangú terrénum és szükségességének számtalan önálló indoka volt. (Csalótzky, 1964: 751) Ilyen önálló indok a közszolgálati kötelezettségek teljesítésének és a közszolgálat rendjének biztosítása. (Tomcsányi, 1926: 356) Ez elmozdulást jelentett a fentebb leírt erős diszkrecionális jogoktól, hiszen az eljárás absztrakt szabályozása már önmagában garanciajelleggel bírt (például a felettes egy személyben már nem bírálhatta el a sérelmes cselekményt, hanem egy, az adott területen szaktudással rendelkező testület tette ugyanezt), s ezen garanciák száma - bár a magyar jogban kissé megkésve és a jogalkotási hibák miatt hiányosan -, de az idő előrehaladtával egyre inkább nőtt.

\section{A fegyelmi felelősség kialakulása és korai története}

A fentebb már ismertetett okok következtében a kiegyezés után elkerülhetetlenné vált a polgári államokban ismert, modern értelmü felelős közszolgálat megteremtése. A polgári állam kiépítése közepette a jogalkotó először 1870-ben jutott el a fegyelmi jog meghatározásához: az első, fegyelmi vétségeket taxációval megállapító és a fegyelmi eljárásra (illetve vizsgálatra) vonatkozó jogot meghatározó jogszabály az 1870. évi XLII. törvénycikk (a továbbiakban: 1870: XLII. tc.) volt, amely a köztörvényhatóságok rendezéséről szólt. (Pétervári, 2018: 135) Ez egy igen kezdetleges szabályozás volt, összesen 10 §-ban szólt az említett témákról. Nemsokára követte az 1872. évi XXXVI. törvénycikk a Buda - Pest fővárosi törvényhatóság alakitásáról és rendezéséről a tisztviselők, valamint a segéd - és kezelőszemélyzet fegyelmi felelősségéről szóló §-ok szövegezése szinte szó szerint megegyezik a köztörvényhatósági törvény azonos témájú rendelkezéseivel. E jogszabályok kezdetlegességét bizonyítja, hogy 1876-ban újabb törvényt fogadtak el, amely már egységesen rendezte a közszolgálati fegyelmi

jogot.

Az 1876. évi VII. törvénycikk parlamenti vitája során két fő érv merült fel a korábbi szabályok módosítása mellett: az egyik érv, amely a kormány szerint a módosítást szükségessé tette a fegyelmi vizsgálat elrendelése feltételeinek kiterjesztése, melynek eredményeképpen a tisztviselők magatartásának sokkal nagyobb köre vált végső soron szankcionálhatóvá, mint előzőleg. (KN 1875/IV. k.: 191) A másik fó érv - mely a leghevesebb vitát váltotta ki - a fegyelmi eljárás lefolytatásának a bírói fórumoktól való elvétele, s a közigazgatás belső szerveire ruházása, arra hivatkozással, hogy az ilyen ügyekben való döntést a bíróságok túl lassan hozzák meg. (KN 1875/IV. k.: 191) A bírói hatáskörök csorbítását a jogállami múködés szempontjából igen aggályosnak kell tekinteni, azonban a közszolgálati 
fegyelmi jogban indokolt az, hogy olyanok ítéljék meg az adott cselekményt (legalábbis alsóbb fokon), akik maguk is rendelkeznek szakmai ismeretekkel és gyakorlattal e téren, valamint - ahogyan a kormány érvelésében is elhangzik - fontos a közigazgatás hibáinak minél hamarabbi javítása. (Bizonyos jogirodalmi álláspont szerint azonban kívánatos lett volna - német mintát követve - felsőbb fokú szervként a Közigazgatási Bíróságot megjelölni, annak 1896-os felállítása után). (Tomcsányi, 1926: 361) Emellett azon tisztviselőt, aki ellen vizsgálat indult általában állásából fel is függesztették, ami az ő szemszögéből bérkiesést, míg a közigazgatás szemszögéből a személyi állomány csökkenését, így lassúbb vagy akár költségesebb ügyintézést jelent, ráadásul előfordulhatott, hogy az adott személyt nem is volt lehetséges pótolni a kieső időre. E szabályozás azonban erős befolyást biztosított a központi kormányzat akaratának érvényesítéséhez, (Papp, 2012/A: 8) s ennek eszközei a közigazgatási bizottság jogköreiben nyilvánultak meg. (Papp, 2012/B: 64) A gyakorlat próbáját azonban e jogszabály sem állta ki. 1886-ban egy nagyobb közigazgatási reform keretében került elfogadásra az 1886. évi XXIII. törvénycikk a közigazgatási tisztviselők, a segéd - és kezelő személyzet tagjai elleni fegyelmi eljárásról, amely jogszabály kiegészülve más jogforrási elemekkel egészen 1929-ig jelentette a fegyelmi vizsgálat, illetőleg eljárás alapját. A változásokat a korábbinál is erősebben érvényesíteni kívánt centralizáció indokolta. (Csizmadia, 1976: 176- 179) A jogszabály teljes körü ismertetése a jelen terjedelmi keretek között nem lehetséges, így a továbbiakban egy konkrét ügyön keresztül való bemutatása tünik a legadekvátabb megoldásnak.

\section{Az 1886: XXIII. tc. szerinti eljárás}

1894 szilveszter éjjelén Pósalaky Mihály polgári biztos és Tóth Sándor rendőrfogalmazó a debreceni Corso kávéházban időztek. Záróra felé- állításuk szerint teljesen józan állapotban- távoztak a helyről, mivel Pósalaky úgy tudta, a helyi tüzoltózenekar még hajnal előtt szerenáddal szeretné ôt lakásán megtisztelni. ${ }^{2}$ Útközben azonban szembetalálkoztak néhány cigányzenésszel, akik állítólag ittasan „,trágár beszélgetést folytatva”, illetve ,,állati orditozás közepette” haladtak az utcán. ${ }^{3}$ Pósalaky biztos rájuk szólt viselkedésük miatt. Az egyik zenész, Danyi Pál erre egy hógömbbel (hógolyóval) fejen vágta Pósalakyt. Ekkorra ért oda Tóth Sándor, aki háza ajtajából fordult vissza, hogy társa segítségére legyen. ${ }^{4}$ A tömeg ekkor látszólag eloszlott, ám Tóth a lakása felé közeledve ismét azt vette észre, hogy , $a$ czigány csoport nagy kaczajjal, hógömbökkel a kezében rohant s öt [Pósalakyt] dobálta. "5 A kisebb dulakodás során Pósalaky a verekedés hevében a földre került. Az eset egy névtelen levél közvetítésével eljutott a rendőrkapitányhoz, aki azt továbbította a polgármesterhez. Ö a Szervezési szabályzat 49. §-a alapján vizsgálatot indított (erre az 1886. évi XXIII. tc. 2 . § b) pontja alapján volt jogosult) Pósalaky és - mivel a levél őt is, mint verekedőt tüntette fel- Tóth ellen, mivel az említett törvénycikk 1. § b) pontja ezt lehetővé tette, ha a tisztviselő „,botrányt okozó erkölcstelen életet él, vagy ilyen nemü kihágást követ el." A vizsgálat lefolytatásával Körner Adolf tanácsnokot bízta meg. ${ }^{6}$ A vizsgálati szakasz egy jelentéssel, egy összefoglaló készítésével zárult le. Ebben az esetben a vizsgálat eredményei a fegyelmi eljárás lefolytatását indokolták, $\mathrm{s}$ ilyen esetben a vizsgálati iratokat a tiszti ügyésznek kellett megküldeni, aki jogosult volt indítványozni az eljárás lefolytatását vagy abbahagyását az ügy ismeretében, illetve - az első esetben - a kiszabandó fenyítéket illetően is javaslatot kellett tenni. A jelen ügyben a tiszti ügyész Tóth Sándor ellen a további eljárást nem látta indokoltnak

\footnotetext{
${ }^{2}$ Magyar Nemzeti Levéltár Hajdú- Bihar Megyei Levéltára (a továbbiakban: MNL- HBML) IV. B. 1414/b. 33. d. $90 / 1894$

${ }^{3}$ U. o.

${ }^{4}$ U. o., ill. MNL- HBML IV. B. 1414/b. 33. d. 276/1895 melléklete- 1895. júl. 5-i jegyzőkönyv

${ }^{5}$ MNL- HBML IV. B. 1414/b. 33. d. 90/1894

${ }^{6}$ MNL- HBML IV. B. 1414/b. 33. d. 90/1895
} 
folytatni, mivel „ellenében a tárgyiratokból oly cselekmény vagy viselkedés, mely fegyelmi vétség tényálladékát megállapithatná [...] nem volt. "7 Pósalakyt illetően már helytállónak találta az eljárás lefolytatását, s a legenyhébb fenyíték, az ún. dorgálás kiszabását javasolta a már hivatkozott törvénycikk 9. §-a alapján. (Itt fontos megjegyezni, hogy a tiszti ügyész csak javasolhatott, de az ügyet végleg néhány esetet kivéve - garanciális okokból a közigazgatási bizottság fegyelmi választmánya hozta, akinek nem volt kötelessége figyelembe venni az indítványt, bár a gyakorlatban nagyobbrészt igazodott az abban foglaltakhoz). A vizsgálat lefolytatása során az érintetteket kihallgatták, vallomásukat jegyzőkönyvben rögzítették. Ezeket illetően két dolgot érdemes kiemelni: egyrészt Tóth és Pósalaky tagadták, hogy ittasak lettek volna, míg a beidézett cigányzenészek ennek ellenkezőjét állították, másrészt Pósalaky fenyegető fellépését kifogásolták s ezt jelölték meg a tettlegesség okaként, míg ezt Pósalaky tagadta. ${ }^{8}$ A két tisztviselő ráadásul jelentéstételi kötelezettségét is megpróbálta elkerülni. ${ }^{9}$ Mindezeket számba véve a közigazgatási bizottság fegyelmi választmánya a tiszti ügyész indítványát teljes mértékben alapul véve hozta meg döntését. ${ }^{10}$

Ilyen esetben a marasztalt tisztviselö nyolc napon belül a belügyminiszterhez fellebbezhetett, ám a jelen esetben ilyenről nem tudunk. (Ez valószínüleg a csekély súlyú fenyítékkel lehet összefüggésben). A tiszti ügyész nem kezdeményezett büntető eljárást, valószínüleg szintén az eset csekély súlya miatt. A korabeli szabályok alapján (1886. évi XXIII. tc. 15-16. §§) ugyanis ha a tiszti ügyész vádiratot nyújtott be, akkor a fegyelmi eljárás a büntető eljárás lefolytatása idejére függőben maradt. Azt azonban, hogy a büntető eljárás lefolytatása után a fegyelmi eljárás is lefolytatásra kerüljön, semmi sem tiltotta. Elképzelhető volt, hogy a cselekmény a bíróság szerint nem képez büncselekményt, ám fegyelmi szempontból ugyanez a cselekmény értékelendő. A büntetöügyben marasztalt tisztviselőt azonban fegyelmi úton is el lehetett marasztalni, ami a ne bis in idem már akkor is alkalmazott elvének sérelmét veti fel, ám az valójában ilyen esetben nem sérült.

\section{6. Összefoglalás}

Összegzésképpen megállapítható, hogy a közszolgálat speciális felelősségi formáinak kialakulása a modern, már müködőképes és a teljes államot átfogó igazgatás létrejötte és fejlődése mentén szinte első perctől - ha nem is kikristályosodott formában, de -jelen volt. A fejlődést az igazgatás - mai kifejezéssel élve - személyzeti politikájának változásai egy egyre inkább egységesülő szabályozás irányába mozdították, ám Magyarországon az egységes szolgálati pragmatika - szemben például a bajor állam 1805-ben kiadott dokumentumával (Sávoly, 1934: 32) - sajnálatos módon nem született meg (Hencz, 1993), bár a korabeli jogirodalomban élénk diskurzus bontakozott ki e témával kapcsolatban, s még tervezetek is készültek. (Pétervári, 2017: 117) Voltak azonban olyan szerzők is, akik úgy vélték, nem róható fel hibául ennek elmaradása, ugyanis az állami szolgálat szerteágazó, s e jellegéből következően nem lehetséges egységes szabályozást alkalmazni rá. (Csiky, 1899: 209)

A fegyelmi felelősség szabályozását illetően megfigyelhető a fent említett fejlődési ív: a kezdeti széttagozódott szabályozás (külön szabályok vonatkoztak például az egyetemi vagy akadémiai jogtanárok, ${ }^{11}$ a tanítók ${ }^{12}$ vagy épp a bábák ${ }^{13}$ fegyelmi felelősségére) a XX. században a rendszerváltást követően teljesen egységesített módon került rendezésre. (Veszprémi, 2011: 171-248) Az e formára

\footnotetext{
${ }^{7}$ MNL- HBML IV. B. 1414/b. 33. d. 1198/1895

${ }^{8}$ MNL- HBML IV. B. 1414/b. 33. d. 276/1895 melléklete- 1895. jan. 9-i jegyzőkönyv

${ }^{9}$ MNL- HBML IV. B. 1414/b. 33. d. 276/1895

${ }^{10}$ MNL- HBML IV. B. 1414/b. 33. d. 1728/1896

${ }^{11} 1897$. évi XXXIV. törvénycikk 24- 25. §§

12 1876. évi XXVII. törvénycikk 7. §

13 1876. évi XIV. törvénycikk 147. §
} 
vonatkozó szabályok (mind anyagi jogi, mind eljárásjogi értelemben) pedig tömegükben nőttek, és, ami fontosabb, garanciális elemekkel bővültek tovább.

\section{Irodalomjegyzék}

1870. évi XLII. törvénycikk

1872. évi XXXVI. törvénycikk

1876. évi VII. törvénycikk

1876. évi XIV. törvénycikk

1876. évi XXVII. törvénycikk

1886. évi XXIII. törvénycikk

1897. évi XXXIV. törvény

Magyar Nemzeti Levéltár Hajdú- Bihar Megyei Levéltára (a szövegben: MNL- HBML) IV. B.1414/b. 33. d. 90/1894

MNL- HBML IV. B. 1414/b. 33. d. 1198/1895

MNL- HBML IV. B. 1414/b. 33. d. 1728/1896

MNL- HBML IV. B. 1414/b. 33. d. 276/1895

MNL- HBML IV. B. 1414/b. 33. d. 276/1895 melléklete- 1895. jan. 9-i jegyzőkönyv

MNL- HBML IV. B. 1414/b. 33. d. 276/1895 melléklete- 1895. júl. 5-i jegyzőkönyv

MNL- HBML IV. B. 1414/b. 33. d. 90/1895

Csalótzky Gy. (1964): Vitaülés a közszolgálat továbbfejlesztésének problémáiról. Állam és Igazgatás XIV. évf. 8. szám: pp. 747-752.

Cserny Á. (2011): A miniszteri felelösség, CompLex Kiadó, Budapest

Cservák Cs. (2015): A hatalommegosztás elmélete és gyakorlata. In: Cservák Cs. (szerk.) (2015): Összehasonlitó alkotmányjogi tanulmányok. Patrocinium Kiadó, Budapest

Csiky Kálmán (1899): A magyar közigazgatási jog kézikönyve joghallgatók és joggyakorlók használatára, Pallas Kiadó, Budapest

Csink L. (2013): Meghaladott-e Montesquieu? A hatalommegosztás modern felfogása. In: Cserny Á. (szerk.) (2013): Ünnepi tanulmányok Rácz Attila 75. születésnapja tiszteletére. Nemzeti Közszolgálati és Tankönyvkiadó Zrt., Budapest

Csizmadia A. (1976): A magyar közigazgatás fejlödése a XVIII. századtól a tanácsrendszer létrejöttéig. Akadémiai Kiadó, Budapest

Gálbory L. (1929): Az önkormányzati alkalmazottak fegyelmi jogáról. A fegyelmi vétség. Magyar Közigazgatás XLVII. évf. 52. szám: pp. 3-5.

Győrfi T. (2001): A kormányzás. In: Kéri L. (szerk.) (2001): Societas Politica. Fejezetek a politikai szociológia köréböl. Bíbor Kiadó, Miskolc

Héjja J. E. (2015): „Hütlenségi és visszaélési botrányos tények” Vármegyei tisztviselői kihágások, felelösségre vonás, fegyelmi eljárás a 19. század elsö felében. Századok CIL. évf. 5. szám: pp. 10691078.

Hencz A. (1993): Gondolatok a közszolgálati pragmatikáról és etikáról 1867- 1944. Magyar Közigazgatás XLIII. évf. 1. szám: pp. 13- 23.

Kelemen M. (2016): Az igazgatás személyi állománya és a közszolgálati jog fejlödése. In: Földi A. (szerk.) (2016): Összehasonlitó jogtörténet. ELTE Eörvös Kiadó, Budapest

Képviselőházi napló 1875. IV. kötet [a szövegben: KN 1875/IV. k.] 
Papp L. (2012): Az önkormányzatiság vázlatos áttekintése, különös tekintettel a hosszú 19. század alkotmányos megoldásaira. De iurisprudentia et iure publico: jog- és politikatudományi folyóirat VI. évf. 1- 2. szám: pp. 97-107. [a szövegben: Papp, 2012/A]

Papp L. (2012): The Concept of Autonomus Local Governments and their Different Forms of Appearances in the Traditions of our National Public Law. Journal on European History of Law III. évf. 1. szám: pp. 62- 64. [a szövegben: Papp, 2012/B]

Pétervári M. (2017): The History of Hungarian Civil Service from the Austro- Hungarian Compromise of 1867 to the First World War. Journal on European History of Law VIII. évf. 1. szám: pp. 116- 120. Pétervári M. (2018): A járások kialakitása Magyarországon az 1870: XLII. tc. alapján. PhD értekezés, Szeged

Sávoly L. (1934): Felelösség a közszolgálatban. Egri Nyomda Rt., Eger

Szabó I. (2017): Néhány gondolat a miniszterek jogi felelösségéről a Lajtán innen és túl. In: Balogh J. (szerk.) (2017): Studia in honorem István Stipta, KRE ÁJK, Budapest

Szamel L. (1986): Az államigazgatás felelösségi rendszere. Közgazdasági és Jogi Kiadó, Budapest Szigeti P. - Takács P. (1998): A jogállamiság jogelmélete. Napvilág Kiadó, Budapest

Tomcsányi M. (1926): A közigazgatási jog alapintézményei. Magyar Királyi Egyetemi Nyomda, Budapest

Veszprémi B. (2011): A köztisztviselök felelösségi rendszere. PhD értekezés, Miskolc 